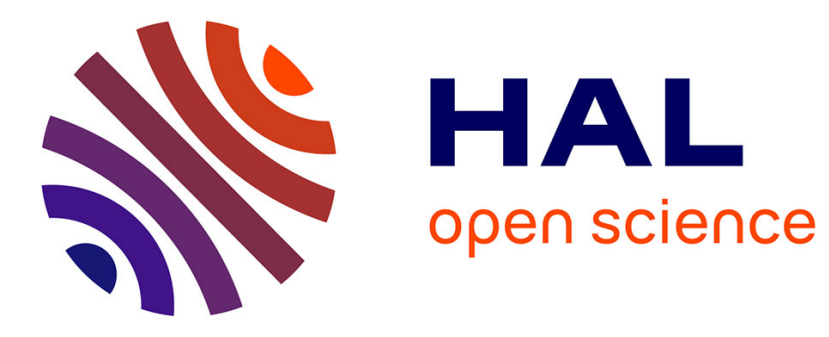

\title{
Mechanotransduction in striated muscle via focal adhesion kinase.
}

\author{
A. C. Durieux, D. Desplanches, D. Freyssenet, M. Flueck
}

\section{To cite this version:}

A. C. Durieux, D. Desplanches, D. Freyssenet, M. Flueck. Mechanotransduction in striated muscle via focal adhesion kinase.. Biochemical Society Transactions, 2007, 35 ( $\mathrm{Pt}$ 5), pp.1312-3. 10.1042/BST0351312 . hal-00187530v2

\section{HAL Id: hal-00187530 \\ https://hal.science/hal-00187530v2}

Submitted on 14 Nov 2007

HAL is a multi-disciplinary open access archive for the deposit and dissemination of scientific research documents, whether they are published or not. The documents may come from teaching and research institutions in France or abroad, or from public or private research centers.
L'archive ouverte pluridisciplinaire HAL, est destinée au dépôt et à la diffusion de documents scientifiques de niveau recherche, publiés ou non, émanant des établissements d'enseignement et de recherche français ou étrangers, des laboratoires publics ou privés. 


\title{
Mechanotransduction in striated muscle via Focal Adhesion Kinase
}

\author{
A.C.Durieux ${ }^{1}$, D. Desplanches ${ }^{2}$, Damien Freyssenet ${ }^{3}$ Martin Flueck $^{1,4}$ \\ ${ }^{1}$ Institute of Anatomy, University of Berne, Bern, Switzerland. \\ ${ }^{2}$ Laboratory of Integrative, Cellular and Molecular Physiology, University of Lyon 1, \\ CNRS, 69622 Villeurbanne, France. \\ 3 Laboratory of Physiology and Physiopathology of Exercise and Handicap, \\ University of Saint Etienne, Saint Etienne, France. \\ ${ }^{4}$ Institute for Biophysical and Clinical Research into Human Movement, Manchester \\ Metropolitan University, Hassall Road, Alsager, Stoke-on-Trent, ST7 2HL, United \\ Kingdom.
}

\begin{abstract}
Contractile tissues demonstrate a pronounced capacity to remodel their composition in response to mechanical challenges. Descriptive evidence suggests the upstream involvment of the phosphotransfer enzyme FAK (focal adhesion kinase) in the molecular control of load-dependent muscle plasticity. Thereby FAK evolves as a myocellular transducer of mechanical signals towards downstream transcript expression in myofibres. Recent advances in somatic gene therapy now allow the exploration of the functional implication of this enzyme in mechanotransduction in intact muscle.
\end{abstract}

Keywords: focal adhesion kinase (FAK), mechanobiology, mechanotransduction, signalling, phosphorylation, striated muscle. 
Mechanical factors exert a key influence on the phenotype of striated muscle [1]. This control is well illustrated by the reversible alterations in size and contractile composition of lower limb muscle. These postural muscle groups undergo considerable atrophy when there are relieved from gravitational mechanical loading for a prolonged period by bedrest or microgravity [2,3]. Conversely, a pronounced degree of fibre hypertrophy is observed with physiological regimes that functionally overload muscle groups $[2,4]$.

Differential modulation of protein breakdown and synthesis and gene expression has been implied as a main mechanism underlying the molecular regulation of this load-dependent muscle plasticity in animal models [5,6]. There is limited knowledge of the critical molecular steps underlying the integration of mechanical signals towards downstream gene and protein expression in intact tissue. Culture studies indicate that both a direct path of mechano-transduction via the hardwired cytoskeleton and mechanically-induced chemical signalling transduce mechanical forces into intracellular responses [7,8]. With regard to the latter mechanochemical signalling, sensory sites along the cytoskeleton-extracellular matrix axis and the plasma membrane have been proposed as points of conversion from mechanical signals into intracellular second messengers. Thereby the activation of a phosphorylation cascade subsequent to the induction of an upstream phosphotransfer enzyme (kinase) appears as the frequent theme for signal propagation towards control of mRNA stability and translation [8-10].

Molecular evidence supports the involvement of two cytoskeletal-associated phosphotransfer activities in the early steps of mechanotransduction in striated muscle (Fig. 1). This concerns a kinase domain in the giant protein titin and the integrinassociated FAK (focal adhesion kinase). With regard to the first example, the titin kinase domain has been proposed to sense mechanical load via confirmation changes [11]. Until recently, titin has been considered to be a simple molecular spring controlling the resting length of sarcomeres. According to new information, titin might also serve as a nodal point for the integration of longitudinal forces with contractile work towards muscle gene expression. Apart from this biophysical information, little data exists to date as to the physiological implication of this titin kinase in muscle turnover.

Conversely, the association of activated FAK signalling with muscle remodelling is well documented. The role of this protein tyrosine kinase in 
myogenesis and mechanosensing was first demonstrated in culture experiments (reviewed in [12]). The phosphotransfer activity of FAK and downstream signalling molecules is activated within minutes after the deformation of integrins by mechanical forces [7]. In striated muscle, FAK is enriched at the myotendinous junction, which is involved in the main mode of force transmission via the myotendinous pathway [13]. Also, FAK localises to sarcolemmal focal adhesion complexes, i.e. costameres, which act as attachment sites for the cytoskeleton (including the Z-discs of the sarcomere) in the fibre interior and the extracellular matrix and neighbouring fibres on the outside (Figure 1). Costameres thereby act as key structures for the transmission of forces via a myofascial pathway [13]. Experimental investigations in chicken and rat models of load-dependent muscle plasticity demonstrate stringent control of the phosphotransfer activity of FAK in slow-twitch muscle by the degree of muscle loading. This is visualized by a 4-fold augmentation of FAK tyrosine phosphorylation in rat soleus muscle after 1 day of functional overload, which exceeds a 2-fold increase in the level of FAK protein [14]. Conversely, FAK tyrosine phosphorylation in the same muscle type is reduced 10-fold after 7 days of muscle unloading by hindlimb suspension when protein levels are little altered. Subsequent investigations into the spatial regulation of FAK have demonstrated that the sarcolemmal localization of this mechanosensory enzyme corresponds to the degree of fibre recruitment [12]. Collectively, the results imply that both expression and post-translational mechanism co-operate in slow-twitch fatigue-resistant muscle to regulate FAK activity by mechanical loading. This suggests further that FAK may be part of the regulatory loop that governs the fate of frequently recruited fibres.

Towards the end of exploring the functional pathways of FAK-mediated mechano-transduction in striated muscle, we have opted for a systems biological setup covering all levels of muscle adaptation. The approach involves the interference with FAK signalling by combined exogenous FAK overexpression via muscle targeted gene transfer and mechanical loading in the hindlimb suspension-reloading model $[6,15]$ and the subsequent measurement of gene expression and structural and functional consequences. This approach has obvious advantages over germline approaches as it offers flexibility in the choice of gene targets and the possibility of an inter-animal control for most muscle groups under investigation via the use of the contralateral muscle. The preliminary results indicate the feasibility of the model approach to investigate the question of FAK-mediated mechano-transduction in vivo 
at the molecular level of resolution. The future use of this technology promises a systematic tool to unravel the paradigm of mechanosensation in contractile tissue.

This work was financially supported by the 'Région Rhône-Alpes', the 'Association Française contre les myopathies’ and the Swiss National Science Foundation.

\section{References}

1 Loughna, P.T., Izumo, S., Goldspink, G. and Nadal-Ginard, B. (1990) Development 109, 217-23.

2 Vandenborne, K., Elliott, M.A., Walter, G.A., Abdus, S., Okereke, E., Shaffer, M., Tahernia, D. and Esterhai, J.L. (1998) Muscle Nerve 21, 1006-12.

3 Narici, M., Kayser, B., Barattini, P. And Cerretelli, P. (2003) Eur. J. Appl. Physiol. 90), 275-82.

4 Flück, M. and Hoppeler, H. (2003) Rev. Physiol. Biochem. Pharmacol. 146, 159216.

5 Booth, F.W. and Thomason, D.B. (1991) Physiol. Rev. 1991 71(2), 541-85.

6 Flück, M., Schmutz, S., Wittwer, M., Hoppeler, H. and Desplanches, D. (2005)

Am. J. Physiol. 289, R4-14.

7 Ingber, D.E. (2006) FASEB J. 20, 811-27.

8 Chiquet, M. and Flück, M. (2001) in Cell and Molecular Responses to Stress, Volume 2 (Storey, K.B. and Storey, J.M.) pp. 97-110, Elsevier Science BV, Amsterdam.

9 Sadoshima, J. and Izumo S. (1997) Annu. Rev. Physiol. 59, 551-71.

10 Proud, C.G (2007) Biochem. J. 403, 217-34

11 Lange, S., Xiang, F., Yakovenko, A., Vihola, A, et al (2005) Science 308, 1599603.

12 Flück, M., Ziemiecki, A., Billeter, R. and Müntener, M.(2002) J. Exp. Biol. 205, 2337-48.

13 Huijing, P.A. (1999). J. Biomech. 32, 329-45.

14 Gordon, S.E., Fluck, M. and Booth, F.W. (2001) J. Appl. Physiol. 90, 1174-83.

15 Durieux, A.C., Bonnefoy, R., Manissolle, C. and Freyssenet, D. (2002) Biochem. Biophys. Res. Commun. 296, 443-50. 


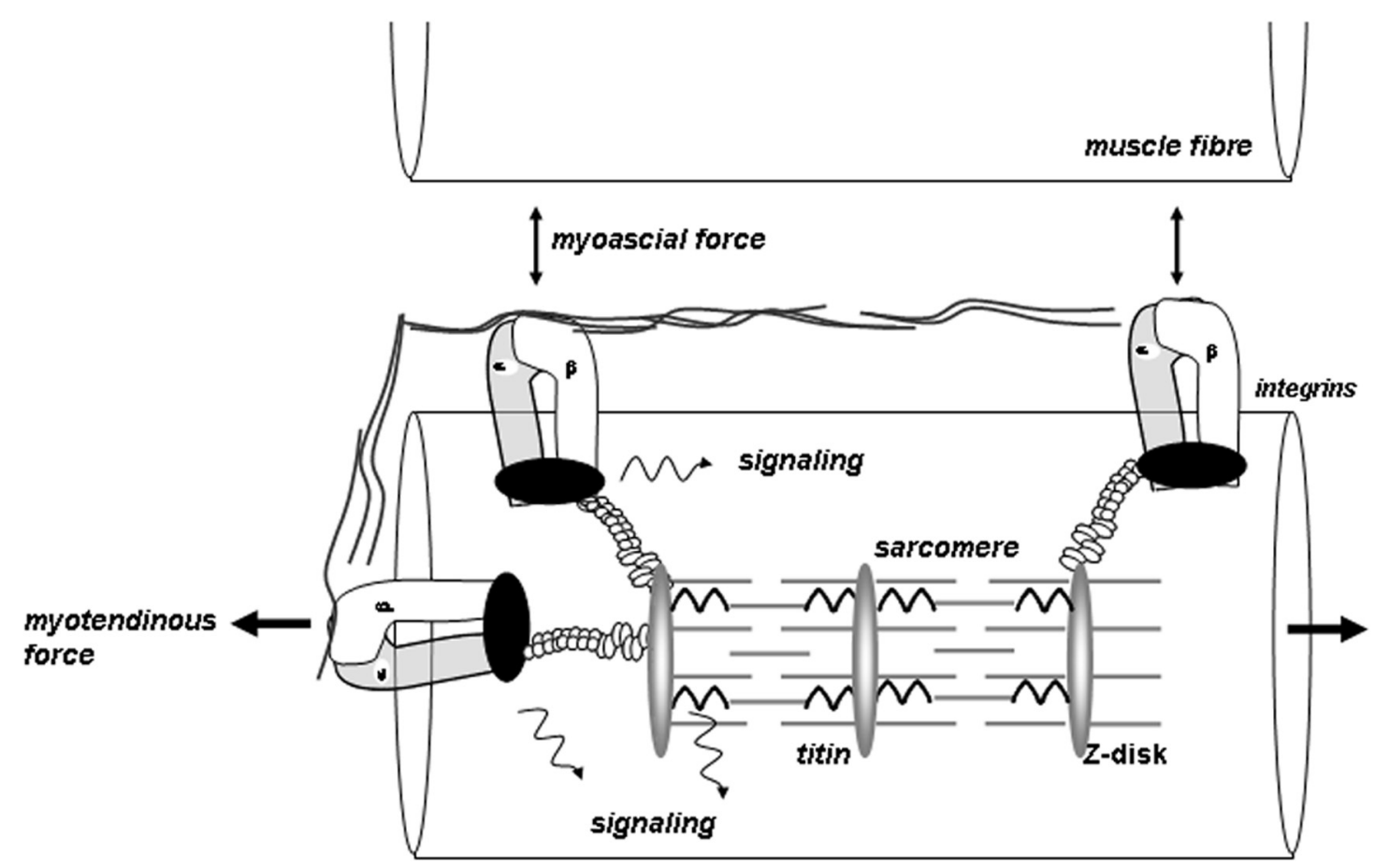

Figure legends

Figure 1: Sketch summarizing the organization of the two proposed routes of mechanochemical signalling in striated muscle via the phosphotransfer activities of FAK and the kinase domain of titin.

It is proposed that the activation of FAK (and titin) following the impact of myofascial and myotendinous forces controls muscle gene expression. 